\title{
Increased phagocytosis and production of reactive oxygen species by neutrophils during magnesium deficiency in rats and inhibition by high magnesium concentration
}

\author{
Françoise I. Bussière ${ }^{1}$, Elyett Gueux ${ }^{1}$, Edmond Rock ${ }^{1}$, Jean-Pierre Girardeau ${ }^{2}$, Arlette Tridon ${ }^{3}$, \\ Andrzej Mazur ${ }^{1}$ and Yves Rayssiguier ${ }^{1 *}$ \\ ${ }^{1}$ Centre de Recherches en Nutrition Humaine d'Auvergne, Unité Maladies Métaboliques et Micronutriments, INRA, Theix, \\ 63122 St-Genès-Champanelle, France \\ ${ }^{2}$ Laboratoire de Microbiologie, INRA, Theix, 63122 St-Genès-Champanelle, France \\ ${ }^{3}$ Laboratoire d'Immunologie, CHRU Clermont-Ferrand, France
}

(Received 20 March 2001 - Revised 3 September 2001 - Accepted 16 October 2001)

\begin{abstract}
Recent studies underline the importance of the immunoinflammatory processes in the pathology of Mg deficiency. Neutrophils possess a superoxide anion-generating NADPH oxidase and its inappropriate activation may result in tissue damage. The aim of the present study was to assess the effect of experimental $\mathrm{Mg}$ deficiency in the rat on polymorphonuclear leucocytes (PMN) activity and the role of increasing extracellular Mg. Weaning male Wistar rats were fed either a $\mathrm{Mg}$-deficient or a control diet for $8 \mathrm{~d}$. In Mg-deficient rats, the characteristic inflammatory response was accompanied by a marked increase in the number of PMN. Higher plasma interleukin 6 and NO concentrations and increased lipid peroxidation in the heart were found in Mg-deficient rats as compared with control rats. As shown by chemiluminescence studies, basal neutrophil activity from $\mathrm{Mg}$-deficient rats was significantly elevated when compared with neutrophils from control rats. Moreover, the chemiluminescence of PMN from Mg-deficient rats was significantly higher than that of control rats following phorbol myristate acetate or opsonized zymosan activation. PMN from Mg-deficient rats also showed an increased activity of phagocytosis in comparison with neutrophils from control animals. Increasing extracellular $\mathrm{Mg}$ concentration in the incubating medium of PMN $(0.8$ v. $8.0 \mathrm{~mm})$ decreased the chemiluminescence activity of PMN from control rats following opsonized zymosan activation. Chemiluminescence activities of PMN from Mg-deficient rats following phorbol myristate acetate or opsonized zymosan challenge were also decreased by high extracellular $\mathrm{Mg}$ concentration. From this work, it appears that PMN activation is an early consequence of $\mathrm{Mg}$ deficiency and that high extracellular $\mathrm{Mg}$ concentration inhibits free radicals generation.
\end{abstract}

\section{Magnesium: Inflammation: Polymorphonuclear leucocytes}

$\mathrm{Mg}$, the second most abundant intracellular cation, plays an essential role in a wide range of fundamental cellular reactions and many signs, symptoms and disease states are attributed to altered $\mathrm{Mg}$ homeostasis (Shils, 1994). In developed countries, the marginal $\mathrm{Mg}$ intake may induce a high prevalence of marginal $\mathrm{Mg}$ deficiency (Galan et al. 1997). Mg deficiency has been extensively studied in the rat, where it is readily produced by dietary depletion. In this experimental model, several studies have provided evidence that $\mathrm{Mg}$ deficiency causes abnormal tissue sensitivity to oxidative stress (Rayssiguier et al. 1993). A particular type of cardiomyopathy has been shown in $\mathrm{Mg}$ deficient animals and it has been considered as the result of free radicals damage (Freedman et al. 1990). A free radical pathogenesis has also been hypothesized in several human cardiovascular diseases associated with $\mathrm{Mg}-$ deficient status (Rayssiguier et al.1997).

Hyperaemia of the ears is the first visible symptom of the experimental Mg-deficiency in rats (Kruse et al. 1932). The metabolism of mast cells and histamine has received much attention since several authors related the characteristic inflammation of $\mathrm{Mg}$-deficiency to increased histamine

\footnotetext{
Abbreviations: HBSS, Hank's balanced salt solution; PMA, phorbol myristate acetate; PMN, polymorphonuclear leucocyte.

* Corresponding author: Dr Y. Rayssiguier, fax + 334736246 38, email yves.rayssiguier@clermont.inra.fr
} 
production (Bois et al. 1963). Recent studies from our laboratory as well as from others suggest that in $\mathrm{Mg}$ deficiency, phagocytes are metabolically stimulated and produce reactive oxygen species leading to tissue damage. The response to $\mathrm{Mg}$-deficiency is accompanied by increased production of $\mathrm{NO}$ and inflammatory cytokines (Weglicki \& Phillips, 1992; Malpuech-Brugère et al. 2000). However, the precise mechanism of this characteristic response to $\mathrm{Mg}$-deficiency remains to be clarified. Neutrophils possess a superoxide anion generating NADPH oxidase and its inappropriate activation may result in tissue damage in inflammatory conditions (Babior, 1984). Moreover, the possibility exists that extracellular $\mathrm{Mg}$ may influence neutrophil function (Simchovitz et al. 1990). Thus, the purpose of the present study was to assess the phagocytic activity and superoxide anion production of blood neutrophils in $\mathrm{Mg}$-deficient rats compared with control animals and the effect of in vitro exposure to $\mathrm{Mg}$.

\section{Materials and methods}

\section{Experimental design}

Male weaning Wistar rats weighing 61 (SE 5) g were randomly divided into $\mathrm{Mg}$-deficient and control groups containing fifty-three and fifty rats respectively. They were maintained from a colony of laboratory animals of the National Institute of Agronomic Research (INRA, Clermont-Ferrand/Theix, France). The institution's guide for the care and use of laboratory animals was used. The rats were housed in wire-bottomed cages in a temperaturecontrolled room $\left(22^{\circ} \mathrm{C}\right)$ with a $12 \mathrm{~h}$ light-dark cycle (lights on at 08.00 hours). They were maintained on the experimental diets for $8 \mathrm{~d}$. Distilled water and diet were provided ad libitum. The synthetic diets contained $(\mathrm{g} / \mathrm{kg})$ : casein 200, sucrose 650, corn oil 50, alphacel 50, DL-methionine 3, choline bitartrate 2, modified AIN-76 mineral mix 35, AIN-76A vitamin mix 10 (ICN biomedicals, Orsay, France). $\mathrm{MgO}$ was omitted from the mineral mix in the Mg-deficient diet. The Mg concentrations of the diets, determined by flame atomic absorption spectrometric analysis, were 20 and $950 \mathrm{mg} / \mathrm{kg}$ for $\mathrm{Mg}$ deficient and control diets respectively. Rats were anaesthetized with pentobarbital $(40 \mathrm{mg} / \mathrm{kg}$ body weight). Blood was collected from the abdominal artery in heparinized and sterile tubes. Plasma obtained after centrifugation $\left(2000 \mathrm{~g}\right.$ for $15 \mathrm{~min}$ ) was stored at $-80^{\circ} \mathrm{C}$ for biochemical analysis. Spleen and hearts were removed. Hearts were kept frozen at $-80^{\circ} \mathrm{C}$ before performing the lipid peroxidation assay.

\section{Polymorphonuclear leucocyte isolation}

Polymorphonuclear leucocytes (PMN) were isolated using a double-layer discontinuous gradient of Histopaque ${ }^{\circledR}-1083$ / 1119 (Sigma Diagnostics, St Louis, MO, USA). After centrifugation $\left(700 \mathrm{~g}, 30 \mathrm{~min}, 20^{\circ} \mathrm{C}\right)$, the layer of PMN was collected and contaminating erythrocytes were lysed by exposure to hypotonic saline. PMN were washed in $\mathrm{Mg}-$ Ca-free buffer and resuspended in modified Hank's balanced salt solution (HBSS; mM: calcium chloride 1.3, magnesium sulfate $0 \cdot 8$, potassium chloride $5 \cdot 4$, potassium phosphate monobasic $0 \cdot 44$, sodium bicarbonate $4 \cdot 2$, sodium chloride 137 , sodium phosphate dibasic $0 \cdot 34$, glucose $5 \cdot 6$, $\mathrm{pH}$ 7.3; Sigma Diagnostics). The purity of neutrophil suspensions averaged $90 \%$ as assessed by May-Grünwald staining. Viability averaged $99 \%$ as tested by Trypan Blue exclusion and was not affected by incubation conditions.

\section{Chemiluminescence studies}

Free radical generation from PMN was measured using a luminometer (LKB-1251; Wallac OY, Turku, Finland). The method for measurement was similar to that described earlier (Wang et al. 1993) with slight modifications. In brief, $3 \times 10^{5}$ PMN were placed in HBSS buffer, $\mathrm{pH} 7 \cdot 4$ and luminol (Sigma Diagnostics) at a final concentration of $0.2 \mathrm{~mm}$ was added. The final volume of the assay mixture was $1000 \mu \mathrm{l}$. The peak of chemiluminescence was recorded and expressed in $\mathrm{mV}$. Opsonized zymosan (Sigma Diagnostics) was prepared as previously described by Hasegawa et al. (1997). An experiment was performed using eight control and eight $\mathrm{Mg}$-deficient rats in order to assess the effect of $\mathrm{Mg}$ deficiency on PMN basal activity and on PMN response to phorbol myristate acetate (PMA Sigma Diagnostics; $1.23 \mu \mathrm{g} / \mathrm{ml}$ ) and opsonized zymosan $(1 \mathrm{mg} / \mathrm{ml})$. Other experiments were performed in order to assess the effect of a high concentration of extracellular $\mathrm{Mg}$ $(8.0$ v. $0.8 \mathrm{~mm})$ on PMN response. In a first experiment, chemiluminescence activity of PMN from control rats ( $n$ 5) was assessed following opsonized zymosan activation. Finally, a second experiment was performed using $\mathrm{Mg}$ deficient animals ( $n$ 8) in order to assess the effect of high concentration of extracellular $\mathrm{Mg}$ on $\mathrm{PMN}$ response to PMA and opsonized zymosan.

\section{Phagocytosis assay}

Phagocytosis studies were performed using five control and five $\mathrm{Mg}$-deficient rats. Bovine septicaemic $E$. coli strain 31A (O153: $\left.\mathrm{K}^{-}: \mathrm{H}^{-}\right)$was used for all experiments. After growth in a Minca medium, bacteria were collected by centrifugation $(1500 \mathrm{~g}, 10 \mathrm{~min})$ and washed with HBSS, bacteria cells were opsonized by normal rodent sera ( $200 \mathrm{ml} / 1 \mathrm{HBSS}$ ) for $30 \mathrm{~min}$ at $37^{\circ} \mathrm{C}$, washed with HBSS and diluted to a concentration of $10^{7}$ cells $/ \mathrm{ml}$ with HBSS containing appropriate antibiotics.

Neutrophils were pelleted by centrifugation and resuspended in RPMI 1640 (Sigma Diagnostics) supplemented with fetal calf serum $(100 \mathrm{ml} / \mathrm{l})$. PMN $\left(4 \times 10^{5}\right)$ were dispensed in wells of Lab-Teck chamber slides (Nunc Inc., Napperville, IL, USA) and allowed to adhere for $30 \mathrm{~min}$ in a humidified $5 \% \mathrm{CO}_{2}$ incubator at $37^{\circ} \mathrm{C}$. Chambers were washed with RPMI 1640 (Sigma Diagnostics) to eliminate non-adherent cells. Opsonized bacteria $\left(4 \times 10^{6}\right)$ were incubated with PMN for $90 \mathrm{~min}$ in $5 \% \mathrm{CO}_{2}$ incubator at $37^{\circ} \mathrm{C}$. Then, the association and phagocytosis of bacteria were determined after staining with a LIVE/DEAD bacLight bacterial viability kit (Molecular Probes, Leiden, The Netherlands). The neutrophil-associated bacteria were counted using a u.v. light microscope. The mean value was 
calculated by averaging the number of bacteria present in 100 cells.

\section{Analytical procedures}

The analytical procedures were performed on eight control and eight $\mathrm{Mg}$-deficient rats except for $\mathrm{Mg}$ determination in PMN. In order to obtain a sufficient amount of PMN for $\mathrm{Mg}$ analysis, PMN from four rats were pooled to obtain six samples for each group before atomic absorption spectrometric analysis. The number of total white cells was determined by a cell counter (Minos Vet, ABX, Montpellier, France). The differential leucocyte counts for polymorphonuclear cells were made from a blood smear stained with the May-Grünwald and Giemsa stain (Sigma, St-Quentin-Fallavier, France). Plasma interleukin 6 concentrations were measured by using bioassays with L929, a fibroblast cell line and B9, a murine hybridoma cell line (Givalois et al. 1994). NO was measured in deproteinized plasma of control and $\mathrm{Mg}$-deficient rats as previously described (Rock et al. 1995a). For lipid peroxidation studies of heart, tissue homogenates were prepared on ice $(1 \mathrm{~g}$ wet tissue $+9 \mathrm{ml} 150 \mathrm{~mm}-\mathrm{KCl})$ using a Polytron homogenizer (Kinematica GMBH, Luzern, Switzerland). Thiobarbituric acid-reactive substances were determined in butylated hydroxy toluene-free tissue homogenates after lipid peroxidation induced by $\mathrm{FeSO}_{4}(10 \mathrm{~mm})$-ascorbate $(250 \mathrm{~mm})$ for $30 \mathrm{~min}$ in a $37^{\circ} \mathrm{C}$ water bath in an $\mathrm{O}_{2}$-free medium as previously described (Rayssiguier et al. 1993). Flame atomic absorption spectrometry (Perkin Elmer 800; Perkin Elmer, St Quentin en Yvelines, France) was used for plasma $\mathrm{Mg}$ concentration and $\mathrm{Mg}$ content of PMN (Gueux et al. 2001). Ionized plasma Mg was determined by using an AVL 977/4 analyser (AVL Medical Instruments, Eragny, France).

\section{Statistical analysis}

Statistical analysis was conducted using InStat package
(Instat; Graph Pad Inc., San Diego, CA, USA). Results were expressed as means values with their standard errors. The statistical significance of differences between means was made by Student's $t$ test or paired Student's $t$ test. When error variance was found to be heterogeneous, the statistical significance between groups was made by using Mann-Whitney test. The differences were considered to be statistically significant when $P$ value was less than 0.05 .

\section{Results}

The classical signs of $\mathrm{Mg}$ deficiency including growth retardation were observed in Mg-deficient rats. Decreased plasma total and ionized $\mathrm{Mg}$ levels indicated that the rats fed the Mg-deficient diet were indeed $\mathrm{Mg}$ deficient (Table 1). Hypomagnesaemia was accompanied by significant increase in blood $\mathrm{Ca}$ concentration. Peripheral vasodilation with hyperaemia of the ears was apparent in all Mg-deficient rats. Spleen weight was significantly higher for Mg-deficient rats compared with controls. The inflammatory response was associated with a marked increase in the number of blood leucocytes and PMN (Table 1). Higher plasma interleukin 6 levels were found in $\mathrm{Mg}$-deficient rats compared with control rats and plasma NO concentrations were increased in Mg-deficient animals as compared with controls. $\mathrm{Mg}$ deficiency increased lipid peroxidation in the heart as shown by thiobarbituric acidreactive substance measurements (Table 1).

Fig. 1 represents the chemiluminescence activity of isolated neutrophils from control and $\mathrm{Mg}$-deficient rats. As expected, neutrophils from control rats displayed a low basal activity. Basal neutrophil activity from $\mathrm{Mg}$-deficient rats was significantly elevated (about 8-fold) when compared with control rats. Neutrophils from control and Mg-deficient rats were responsive to PMA and opsonized zymosan. However, the chemiluminescence activity of PMN from Mg-deficient rats was significantly higher than cells from control rats following PMA or opsonized zymosan activation. Phagocytosis study indicated an

Table 1. Characteristics of rats fed either the control or the magnesium-deficient diet†‡

(Mean values with their standard errors)

\begin{tabular}{|c|c|c|c|c|}
\hline & \multicolumn{2}{|c|}{ Control } & \multicolumn{2}{|c|}{ Mg-deficient } \\
\hline & Mean & SE & Mean & SE \\
\hline Body weight (g) & 109 & 2 & $97^{\star *}$ & 2 \\
\hline Plasma Mg (mmol/l) & 0.82 & 0.01 & $0 \cdot 17^{\star \star \star}$ & 0.03 \\
\hline Plasma Ca $(\mathrm{mmol} / \mathrm{l})$ & $2 \cdot 64$ & 0.03 & $2 \cdot 86^{\star \star}$ & 0.06 \\
\hline Plasma ionized $\mathrm{Mg}(\mathrm{mmol} / \mathrm{l})$ & 0.49 & 0.01 & $0 \cdot 18^{\star \star}$ & 0.02 \\
\hline Relative spleen weight ( $\mathrm{g} / \mathrm{kg}$ body weight) & 4.4 & 0.3 & $10 \cdot 4^{\star \star *}$ & 0.9 \\
\hline $\begin{array}{l}\text { Leucocytes }\left(10^{9} \mathrm{cells} / \mathrm{l}\right) \\
\text {. }\end{array}$ & $5 \cdot 19$ & 0.5 & $18 \cdot 2^{\star * \star}$ & $2 \cdot 1$ \\
\hline PMN $\left(10^{9} \mathrm{cells} / \mathrm{l}\right)$ & 1.3 & 0.2 & $8 \cdot 4^{\star * *}$ & $1 \cdot 3$ \\
\hline PMN Mg (ng Mg/ $10^{6}$ cells) & 52 & 4 & 64 & 6 \\
\hline Interleukin $6(\mathrm{pg} / \mathrm{ml})$ & 33 & 2 & $116^{* * *}$ & 17 \\
\hline $\mathrm{NO}(\mu \mathrm{mol} / \mathrm{l})$ & 4.2 & 0.3 & $8 \cdot 1^{* * *}$ & 0.4 \\
\hline Heart peroxidation (TBARS nmol/g wet wt) & 256 & 16 & $350^{\star * *}$ & 11 \\
\hline
\end{tabular}

PMN, polymorphonuclear leucocytes; TBARS, thiobarbituric acid-reactive substances.

Mean values were significantly different from those of the control group: ${ }^{\star \star} P<0.01,{ }^{\star * \star} P<0.001$. $\dagger$ For details of diets and procedures, see pp. 108-109.

$\ddagger$ Mean values are for eight rats per group, except for the Mg content of PMN in which case the values are for six samples each pooled from four animals within each group. 


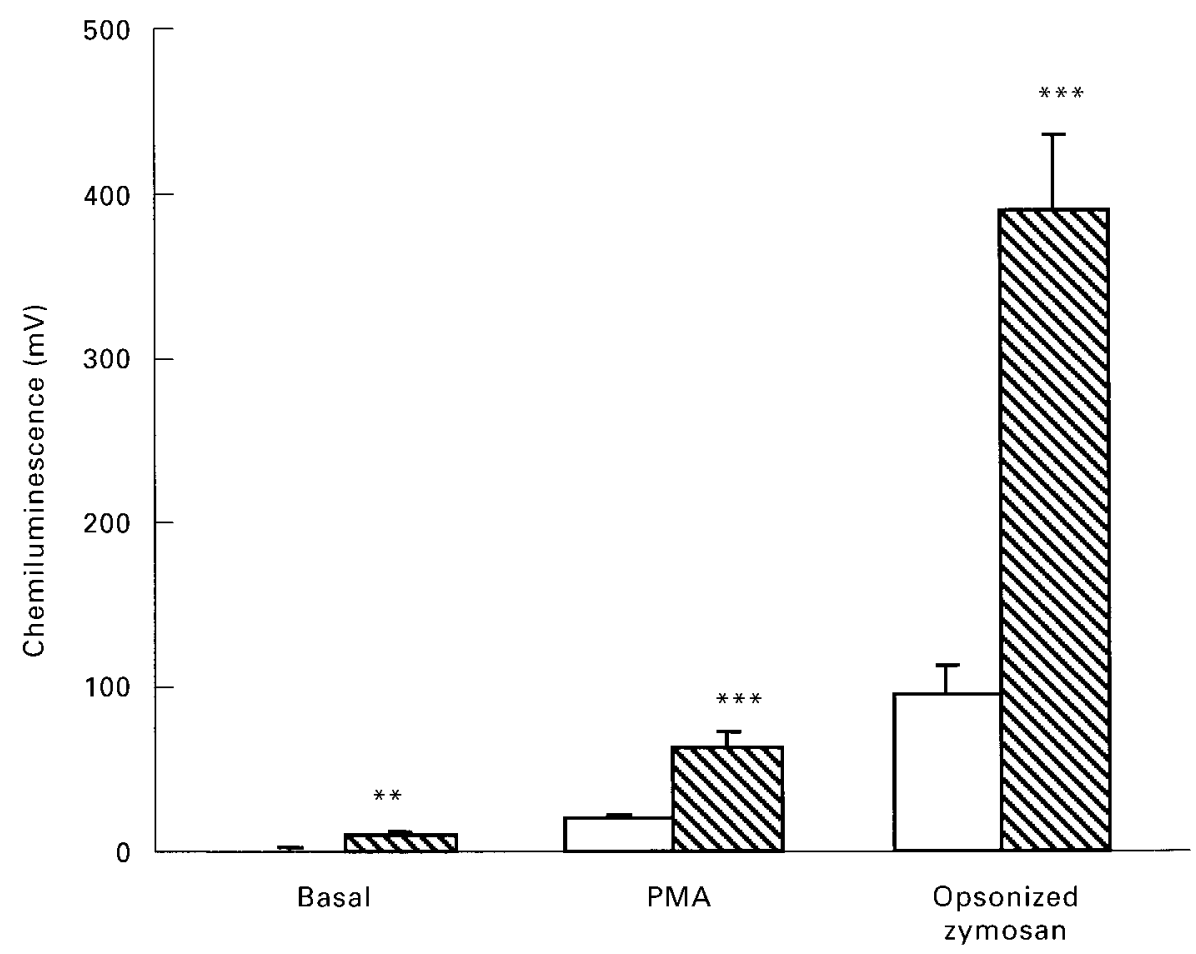

Fig. 1. Polymorphonuclear leucocyte activation in control $(\square)$ and Mg-deficient $(\mathbb{\nabla})$ rats. Their reactive oxygen species producing activities were determined by chemiluminescence, basal or in the presence of phorbol myristate acetate (PMA) or opsonized zymosan. For details of diets and procedures, see pp. 108-109. Values are means for eight rats per group, with their standard errors represented by vertical bars. Mean values were significantly different from those of the control group: ${ }^{* \star} P<0 \cdot 01,{ }^{\star * \star} P<0.001$.

increased capacity of PMN from Mg-deficient rats to adhere to glass (results not shown) and PMN from $\mathrm{Mg}$-deficient rats showed an increased activity of phagocytosis in comparison with neutrophils from control animals (Table 2).

High concentrations of $\mathrm{Mg}(8.0$ v. $0.8 \mathrm{~mm})$ significantly decreased the chemiluminescence activity in PMN from control rats following opsonized zymosan challenge (39 (SE 10) $\mathrm{mV} v$. 111 (SE 22) $\mathrm{mV}$; $n$ 5, P<0.05). Similarly, increasing extracellular $\mathrm{Mg}$ concentration significantly decreased the chemiluminescence activity in PMN from Mg-deficient rats following PMA or opsonized zymosan activation (Table 3 ).

\section{Discussion}

Dietary $\mathrm{Mg}$ deficiency in rats gives rise after a few days to a characteristic allergy-like crisis, the first visible symptom being a peripheral vasodilation (Nishio et al. 1988). The inflammatory response is associated with a marked increase in total circulatory leucocytes, predominantly in the neutrophil fraction (Kurantsin-Mills et al. 1997; Malpuech-Brugère et al. 2000). Previous observations point to the spontaneous and non-infectious induction of the inflammatory process in this experimental model (Malpuech-Brugère et al. 1998). Leucocytosis was associated to cellular hyperplasia of cell lines in the bone marrow (McCreary et al. 1967) while the greater spleen size in Mgdeficient rats is believed to be due to infiltration of the spleen with PMN and macrophages (Malpuech-Brugère et al. 1998). Inflammatory agonists including cytokines are elevated in Mg-deficient rats (Malpuech-Brugère et al. 2000). The present study confirms that Mg-deficiency elevates circulatory levels of interleukin 6 , this cytokine being responsible for the synthesis of acute-phase reactants

Table 2. Neutrophil phagocytosis in response to opsonized bacteria in control and magnesium-deficient rats†‡

(Mean values with their standard errors for five rats per group)

\begin{tabular}{llllllll}
\hline & \multicolumn{2}{c}{ Control } & & \multicolumn{2}{c}{ Mg-deficient } \\
& & Mean & SE & & Mean $\quad$ SE \\
\hline Number of intracellular bacteria/activated neutrophils & & 0.1 & 0.05 & & $8.0^{*}$ & 2.2 \\
\hline
\end{tabular}

Mean value was significantly different from that of the control group: ${ }^{*} P<0.05$.

†For details of diets and procedures, see pp. 108-109.

¥Phagocytosis was evaluated by counting bacteria incorporated in neutrophils and is expressed in number of bacteria/activated cells. 
Table 3. Effect of extracellular magnesium concentration on reactive oxygen species neutrophils production after activation with phorbol myristate acetate (PMA) or opsonized in magnesiumdeficient rats $† \ddagger$

(Mean values with their standard errors for eight rats per group)

Extracellular Mg concentrations

\begin{tabular}{lccccc}
\cline { 2 - 3 } \cline { 5 - 6 } & \multicolumn{2}{c}{$0.8 \mathrm{mM}$} & & \multicolumn{2}{c}{$8.0 \mathrm{mM}$} \\
\cline { 2 - 3 } \cline { 5 - 6 } & Mean & SE & & Mean & SE \\
\hline PMA & 76 & 16 & & $54^{\star *}$ & 12 \\
Opsonized zymosan & 262 & 27 & & $112^{\star *}$ & 15 \\
\hline
\end{tabular}

†For details of diets and procedures, see pp. 108-109.

$\ddagger$ Reactive oxygen species production was determined by chemiluminescence and expressed in $\mathrm{mV}$.

Mean values at $0.8 \mathrm{~mm}$ were significantly different from those at $8.0 \mathrm{~mm}$ : ${ }^{* *} P<0.01$.

(Malpuech-Brugère et al. 2000). The involvement of free radicals in $\mathrm{Mg}$ deficiency is well documented in spite of the difficulty of demonstrating their presence of effects in vivo. Tissues of $\mathrm{Mg}$-deficient rats had a greater tendency to undergo lipid peroxidation than do tissues of control animals as shown by measurement of thiobarbituric acid-reactive substances (Rayssiguier et al. 1993). Other studies with a spin-trapping technique also indicated that $\mathrm{Mg}$ deficiency results in an increase in production of free radicals (Rock et al. 1995). Increased circulating levels of NO may be the result of excessive NO production by activated cells during the inflammatory response and may contribute to the increased oxidative stress due to the formation of peroxynitrites (Rock et al. 1995a,b; Mak et al. 1996).

Neutrophils are well known as a prominent cell type during acute inflammation and those cells find an important role through activities such as phagocytosis, production of reactive oxygen species and as a source of immunoregulatory cytokines (Cassatella, 1995). It is now recognized that respiratory burst enzymatic complex, a plasmamembrane-bound NADPH oxidase is normally dormant in resting cells. Upon several forms of cell activation, this oxidase becomes activated by a series of complex intracellular processes and reduces oxygen in one electron step to form superoxide anion, which is the primary product of the oxidative burst (Babior, 1984). The link between the external environment of the neutrophil and the activation of its function (chemotaxis, adherence, phagocytosis, oxidase activation, degranulation) is provided by the plasma membrane receptors (Edwards, 1991). Neutrophils isolated from $\mathrm{Mg}$-deficient rats after $8 \mathrm{~d}$ on the deficient diet generate higher blood levels of superoxide anion as shown by chemiluminescence activity. Thus, PMN which are found in greater number in the blood of $\mathrm{Mg}$-deficient rats are activated endogenously. As neutrophil activation is a major source of cellular oxidants, it contributes to an increase in oxidative stress in this experimental model. In vitro, neutrophils can respond to different agonists. PMA is a direct protein kinase $\mathrm{C}$ activator while opsonized zymosan gives rise to a more complex transduction signal implicating membrane receptors and internalization process (Edwards, 1991). Superoxide anion production following PMA or opsonized zymosan was higher in PMN from Mgdeficient animals as compared with control animals, i.e. these cells had an enhanced response to stimulation. This result is consistent with previous results (MalpuechBrugère et al. 2000). The chemiluminescence activity of resident macrophages from $\mathrm{Mg}$-deficient rats was higher compared with cells from control rats and are primed for superoxide production following PMA stimulation. In another study, a longer period of Mg-deprivation was necessary to obtain an increase in basal activity of neutrophils and upon challenge with PMA, PMN from Mgdeficient animals exhibited no significant activation, suggesting that these cells were unable to be further stimulated (Mak et al. 1997). By contrast, the present experiment clearly indicates that PMN activation is an early consequence of $\mathrm{Mg}$ deficiency and that primed PMN are able to be further stimulated by various activators. These discrepancies may be related to a cellular response that is probably different in the acute phase, as shown in the present experiment, compared with a longer period of deficiency.

The underlying mechanism for inflammatory response in $\mathrm{Mg}$-deficiency remains unclear. The possibility that an inflammatory response induced by $\mathrm{Mg}$-deficiency was initiated by an early neurogenic inflammatory process through the secretion of substance $\mathrm{P}$ was suggested (Weglicki \& Phillips, 1992), but in the same experimental model as that in the present experiment, high levels of interleukin 6 were detected without a significant increase in the circulating level of substance $P$ (Malpuech-Brugère et al. 2000). There is increasing evidence of the importance of a cytokine cascade in the induction and control of the inflammatory reaction. It is well known that exposure of PMN to cytokines leads to a rapid increase in expression of some plasma membrane receptors and primes the respiratory burst to generate elevated levels of oxidants (Edwards, 1991). Thus, inflammatory cytokines may upregulate neutrophil function in Mg-deficient rats. It was also suggested that $\mathrm{NO}$ overproduction during $\mathrm{Mg}$ deficiency participates in the neutrophil activation process (Mak et al. 1997). The present study indicates that a high extracellular $\mathrm{Mg}$ concentration is able to attenuate neutrophil respiratory burst in control rats. Chemiluminescence activities of PMN from Mg-deficient rats were also decreased following PMA or opsonized zymosan challenge. Since this phenomenon was observed whatever the activator used, $\mathrm{Mg}$ may act via a non-specific mechanism. $\mathrm{Ca}$ is also recognized as an important second messenger in the signalling process of neutrophil oxidative burst by stimulating protein kinase $\mathrm{C}$. Increased influx of $\mathrm{Ca}$ from the extracellular space and release from intracellular stores are important in the oxidative burst (Snyderman \& Uhing, 1992). Mg acts as a natural Ca antagonist (Iseri \& French, 1984) and the possibility exists that decreased extracellular $\mathrm{Mg}$ increases intracellular $\mathrm{Ca}$ and that an increase in extracellular $\mathrm{Mg}$ has the opposite effect. Thus, increasing external concentration of $\mathrm{Mg}$ may have beneficial antiinflammatory effects while a reduction in the extracellular $\mathrm{Mg}$ concentration might participate in phagocytic cell activation. The increase in plasma $\mathrm{Ca}$ concentration is a well-known response in Mg-deficient rats (Rayssiguier et al. 1982) and the possibility exists that $\mathrm{Ca}$ elevation participates in the phagocytic cell activation by a further 
decrease in the $\mathrm{Mg}: \mathrm{Ca}$ extracellular ratio. This hypothesis concerning the effect of extracellular $\mathrm{Mg}$ concentration on cellular response is supported by in vivo studies showing enhanced tumour necrosis factor- $\alpha$ production following endotoxin challenge in $\mathrm{Mg}$-deficient rats and suggesting the inhibitory effect of high concentration of $\mathrm{Mg}$ on cytokine production (Malpuech-Brugère et al. 1999). Feeding the animals with $\mathrm{Mg}$-deficient diet results in a rapid decline in plasma $\mathrm{Mg}$ while the $\mathrm{Mg}$ cellular concentration falls only slightly in muscles and soft tissues (Vormann et al. 1997) and do not fall at all in PMN. Plasma and interstitial body fluids represent the central compartment of $\mathrm{Mg}$ metabolism. This central compartment containing only $1 \%$ total body $\mathrm{Mg}$ is connected to several peripheral compartments like muscles and soft tissues. Bone $\mathrm{Mg}$ is the most important store. However, when $\mathrm{Mg}$ intake is severely restricted in rapidly growing rats, renal conservation and bone mobilization are not enough to permit plasma $\mathrm{Mg}$ homeostasis (Classen et al. 1994). The decrease in plasma $\mathrm{Mg}$ is accompanied by a decrease in ionized plasma $\mathrm{Mg}$, as shown in the present experiment. However, the percentage of ionized plasma $\mathrm{Mg}$ in $\mathrm{Mg}$-deficient rats was increased as compared with control rats as shown previously (Zimmerman et al. 2000).

We have found that PMN activation is an early consequence of $\mathrm{Mg}$ deficiency and the exact mechanism of this effect is under investigation. $\mathrm{Mg}$ deficiency induces an acute-phase inflammatory response that is followed by a chronic inflammatory phase (Weglicki \& Philips, 1992; Rayssiguier et al. 2001). However, inflammation may be switched off by inhibitory mechanisms and additional studies are needed to determine if $\mathrm{Mg}$ deficiency of long duration induces exhausted activity of phagocytic cells (Nishio et al. 2001). The inhibitory effect of supraphysiological Mg level on leucocyte activation was demonstrated in vitro. Further studies are needed to assess if increasing $\mathrm{Mg}$ concentration in vivo results in a decrease in leucocyte activation. Although the relevance of the findings of the present experiment to the disease process remains to be established, the results suggest the importance of the immuno-inflammatory process in the pathology of $\mathrm{Mg}$ deficiency. The hypothesis that $\mathrm{Mg}$ deficiency can lead to enhanced atherogenesis through the inflammatory process has been recently presented. Moreover, $\mathrm{Mg}$ deficiency amplifies myocardial vulnerability to toxic agents including ischaemia-reperfusion (Seelig, 1989). The role of PMN in ischaemia-hypoxia reperfusion damage is well documented. Migration of PMN into the ischaemic tissues, reactive oxygen species generation, release of other cytotoxic substances has been demonstrated (Sethi et al. 1999). Protection against ischaemia and reperfusion injury has been reported after treatment with Mg (Shibata et al. 1999). The results of the present experiment are consistent with the hypothesis that changes in the response of phagocytic cells resulting from an increase in plasma $\mathrm{Mg}$ may contribute to the protective effects of this cation.

\section{Acknowledgement}

The authors would like to thank the expert technical assistance of C. Lab.

\section{References}

Babior BM (1984) The respiratory burst of phagocytes. Journal of Clinical Investigation 73, 599-601.

Bois P, Gascon A \& Beaulnes A (1963) Histamine-liberating effect of magnesium deficiency in the rat. Nature 187, 501-502.

Cassatella MA (1995) The production of cytokines by polymorphonuclear neutrophils. Immunology Today 16, 21-26.

Classen UG, Seitz G, Grimm P \& Classen HG (1994) Influence of high and low dietary magnesium levels on functional, chemical and morphological parameters of old rats. Magnesium Research 7, 233-243.

Edwards SW (1991) Regulation of neutrophil oxidant production. In Calcium, Oxygen Radicals and Cellular Damage, pp. 35-75 [CJ Duncan, editor]. Cambridge: University Press.

Freedman AM, Atrakchi AH, Cassidy MM, Muesing RA \& Weglicki WB (1990) Magnesium deficiency-induced cardiomyopathy: protection by vitamin E. Biochemical Biophysical Research Communication 170, 1102-1106.

Galan P, Preziosi P, Durlach V, Valeix P, Ribas L, Bouzid D, Favier A \& Hercberg S (1997) Dietary magnesium intake in a French adult population. Magnesium Research 10, 321-328.

Givalois L, Dornand J, Mekaouche M, Solier MD, Bristow AF, Ixart G, Siaud P, Assenmacher I \& Barbanel G (1994) Temporal cascade of plasma level surges in ACTH, corticosterone, and cytokines in endotoxin-challenged rats. American Journal of Physiology 276, R164-R170.

Gueux E, Bussière F \& Rayssiguier Y (2001) Magnesium content of polymorphonuclear blood cells is not an indicator of magnesium status. In Advances in Magnesium Research: Nutrition and Health [Y Rayssiguier, A Mazur and J Durlach, editors]. London: John Libbey \& Co Ltd (In the Press).

Hasegawa H, Suzuki K, Nakaji S \& Sugawara K (1997) Analysis and assessment of the capacity of neutrophils to produce reactive oxygen species in a 96-well microplate format using lucigenin- and luminol-dependent chemiluminescence. Journal of Immunological Methods 210, 1-10.

Iseri LT \& French JH (1984) Magnesium: nature's physiologic calcium blocker. American Heart Journal 108, 188-193.

Kruse HD, Orent ER \& McCollum EV (1932) Studies on magnesium deficiency in animals. I. Symptomatology resulting from magnesium deprivation. Journal of Biological Chemistry 96, 519-539.

Kurantsin-Mills J, Cassidy MM, Stanfford RE \& Weglicki WB (1997) Marked alterations in circulating inflammatory cells during cardiomyopathy development in a magnesium-deficient rat model. British Journal of Nutrition 78, 845-855.

McCreary PA, Battifora H, Hahneman BM, Laing GH \& Hass GM (1967) Leukocytosis, bone marrow hyperplasia and leukemia in chronic magnesium deficiency in the rat. Blood 29, 683-690.

Mak IT, Dickens BF, Komarov AM, Wagner TL, Phillips TM \& Weglicki WB (1997) Activation of the neutrophil and loss of plasma glutathione during $\mathrm{Mg}$-deficiency modulation by nitric oxide synthase inhibition. Molecular and Cellular Biochemistry 176, 35-39.

Mak IT, Komarov AM, Wagner TL, Stafford RE, Dickens BF \& Weglicki WB (1996) Enhanced NO production during $\mathrm{Mg}$ deficiency and its role in mediating red blood glutathione loss. American Journal of Physiology 271, C385-C390.

Malpuech-Brugère C, Kuryszko J, Nowacki W, Rock E, Rayssiguier Y \& Mazur A (1998) Early morphological and immunological alterations in the spleen during magnesium deficiency in the rat. Magnesium Research 11, 161-169.

Malpuech-Brugère C, Nowacki W, Daveau M, Gueux E, Linard C, Rock E, Lebreton J-P, Mazur A \& Rayssiguier Y (2000) 
Inflammatory response following acute magnesium deficiency in the rat. Biochimica et Biophysica Acta 1501, 91-98.

Malpuech-Brugère C, Nowacki W, Rock E, Gueux E, Mazur A \& Rayssiguier Y (1999) Enhanced tumor necrosis factor- $\alpha$ production following endotoxin challenge in rats is an early event during magnesium deficiency. Biochimica et Biophysica Acta 1453, 35-40.

Nishio A, Ishiguro S, Ikegaki I, Matsumoto S, Yoshimitsu F \& Miyazaki A (1988) Histamine metabolism and pinnal hyperaemia during magnesium deficiency in rats. Magnesium Research 1, 155-161.

Nishio A, Kikuchi K, Miyamoto A \& Ishiguro (2001) Phagocytosis by alveolar macrophages during dietary magnesium deficiency in adult rats. Magnesium Research 14, 120-121, Abstr.

Rayssiguier Y, Bussière FI, Gueux E, Rock E \& Mazur A (2001) Acute phase response in magnesium deficiency: possible relevance to atherosclerosis. In Advances in Magnesium Research: Nutrition and Health [Y Rayssiguier, A Mazur and J Durlach, editors] London: John Libbey \& Co. Ltd (In the Press).

Rayssiguier Y, Gueux E, Bussière L, Durlach J \& Mazur A (1993) Dietary magnesium affects susceptibility of lipoproteins and tissues to peroxidation in rats. Journal of American College of Nutrition 12, 133-137.

Rayssiguier Y, Malpuech C, Nowacki W, Rock E, Gueux E \& Mazur A (1997) Inflammatory response in magnesium deficiency. In Advances in Magnesium Research: 1. Magnesium in Cardiology, Suppl. 1, Magnesium Research, pp. 415-421 [R Smetana, editor]. London: John Libbey \& Co Ltd.

Rayssiguier Y, Thomasset M, Garel J-M \& Barlet J-P (1982) Plasma parathyroid hormone levels and intestinal calcium binding protein in magnesium deficient rats. Hormone and Metabolic Research 14, 379-382.

Rock E, Astier C, Lab C, Nowacki W, Gueux E, Mazur A \& Rayssiguier Y (1995a) Magnesium deficiency in rats induces a rise in plasma nitric oxide. Magnesium Research 8, 237-242.

Rock E, Astier C, Lab C, Vignon X, Gueux E, Motta C \& Rayssiguier Y (1995b) Dietary magnesium deficiency in rats enhances free radical production in skeletal muscle. Journal of Nutrition 125, 1205-1210.
Seelig M (1989) Cardiovascular consequences of magnesium deficiency and loss: Pathogenesis, prevalence and manifestationsmagnesium and chloride loss in refractory potassium repletion. American Journal of Cardiology 63, 4G-21G.

Sethi S, Songh MP \& Dikshit M (1999) Nitric oxide-mediated augmentation of polymorphonuclear free radical generation after hypoxia-reoxygenation. Blood 93, 333-340.

Shibata M, Ueshima K, Harada M, Nakamura M, Hiramori K, Endo S, Sato N, Mukaida H, Suzuki T, Suzuki T \& Inada K (1999) Effect of magnesium sulfate pretreatment and significance of matrix metalloproteinase- 1 and interleukin-6 levels in coronary reperfusion therapy for patients with acute myocardial infarction. Angiology 50, 573-582.

Shils ME (1994) Magnesium. In Modern Nutrition in Health and Disease, pp. 164-184 [ME Shils, JA Olson and M Shike, editors]. Malvern: Lea and Febiger.

Simchovitz L, Foy MA \& Cragoe EJ (1990) A role for $\mathrm{Na}^{+} / \mathrm{Ca}^{2+}$ exchange in the generation of superoxide radicals by human neutrophils. Journal of Biological Chemistry 265, 13449-13456.

Snyderman R \& Uhing RJ (1992) Chemoattractant StimulusResponse Coupling. In Inflammation: Basic Principles and Clinical Correlates, pp. 421-439 [JI Gallin, IM Goldstein and R Snyderman, editors]. New York, NY: Raven Press.

Vormann J, Günther T, Höllriegl V \& Schümann K (1997) Pathobiochemical effects of graded magnesium deficiency in rats. In Advances in Magnesium Research: Magnesium in Cardiology, pp. 422-434 [R Smetana, editor]. London: John Libbey \& Co Ltd.

Wang J-F, Komarov P \& de Groot H (1993) Luminol chemiluminescence in rat macrophages and granulocytes: The role of $\mathrm{NO}, \mathrm{O}_{2}{ }^{-} / \mathrm{H}_{2} \mathrm{O}_{2}$, and $\mathrm{HOCl}$. Archives of Biochemistry and Biophysics 304, 189-196.

Weglicki WB \& Phillips TM (1992) Pathobiology of magnesium deficiency: a cytokine/neurogenic inflammation hypothesis. American Journal of Physiology 263, R734-R737.

Zimmermann P, Weiss U, Classen HG, Wendt B, Epple A, Zollner H, Temmel W, Weger M \& Porta S (2000) The impact of diets with different magnesium contents on magnesium and calcium in serum and tissues of the rat. Life Science 67, 949-958. 